\title{
Relationships Between Odontocete Distributions and Zooplankton Community Structure Along the Southern Edge of Georges Bank
}

\author{
R. B. Griffin \\ University of Rhode Island Graduate School of Oceanography \\ Narragansett, Rhode Island 02882, USA
}

\begin{abstract}
From 1 June to 2 July 1993, the National Oceanic and Atmospheric Administration, National Marine Fisheries Service, Marine Mammal Investigation, Woods Hole, MA, undertook a shipboard survey on distributions and abundances of cetacean species on the eastern and southern edges of Georges Bank. During transects of the study area, concurrent physical and biological data were collected to examine characteristics of marine mammal habitat. Zooplankton communities were sampled by double oblique bongo tows. Odontocete sighting rates (animals per hour) and their mean group sizes within $20 \mathrm{~km}$ of bongo stations were compared with $\log _{10}$ copepod density. Sighting rates of striped (Stenella coeruleoalba) and common dolphins (Delphinus delphis) increased with decreasing copepod density and increasing copepod diversity. Zooplankton community structure was found useful in understanding oceanographic characteristics of the habitat of odontocete species.
\end{abstract}

Key words: abundance, dolphins, distribution, Georges Bank, whales, zooplankton

\section{Introduction}

Low variance estimates of species abundances and distributions are essential to properly manage or protect species impacted by commercial fisheries. To better effect this goal, a refined understanding of cetacean and other apex predator distributions from an ecosystem/community viewpoint is needed. This approach was recommended by the International Whaling Commission and the International Council for the Exploration of the Sea (IWC, 1992), and studies have suggested that surveys should focus on oceanographic structure, prey species distribution and density dependent habitat selection (Smith et al., 1996).

Marine mammals are best understood as part of an ecosystem. Species distributions are influenced by complex environmental interactions, which exert selective pressure to direct their evolution. Feeding ecology and reproductive behaviors are likely prime factors in the distributions of cetaceans (Gaskin, 1976), and mesoscale oceanographic features affecting prey distributions may be important factors affecting cetacean distribution (Selzer and Payne, 1988). Thus, studies of relationships between the environment, prey species and cetacean species distributions may aid in describing marine mammal habitat.

The distribution of cetacean species have frequently been described in terms of physical oceanographic variables. For example, distributions of many species in the western Atlantic were explained by water depth (CETAP, 1982). White-sided dolphins (Lagenorhynchus acutus) in the northwestern Atlantic Ocean were observed in areas of high topographic relief, low temperature and low salinity, while common dolphins (Delphinus delphis) were found in areas of high sea-floor relief where temperatures were warmer and more saline (Selzer and Payne, 1988). In the eastern tropical Pacific (ETP), the delphinid and sperm whale (Physeter macrocephalus) habitat use was significantly related to sea surface temperature and thermocline topography (Polacheck, 1987; Reilly and Fiedler, 1994). Quality of physical habitat (defined as a cetacean community ordination function of surface temperature, thermocline depth and thermocline thickness) was significantly related to delphinid species abundance estimates (Fiedler and Reilly, 1994). 
Prey fish abundance significantly explained variation in cetacean sighting rates in the Northwest Atlantic (Waring, 1995). Similarly, a high level of spatial correlation was found between the occurrence of fish larvae and their zooplankton food source. Seasonal, seaward progression in spawning activity of fish species off Southwest Ireland and larval fish behavior appeared influenced by zooplankton distributions (Doyle and Ryan, 1989). In the North Sea, herring, cod and flatfish recruitment rates were associated with fluctuations in Calanus sp. abundance (Pepin, 1990), and diversity and abundance of herring were shown to be a function of zooplankton concentrations off the Atlantic coast of Nova Scotia (Stone and Jessop, 1992).

Relationships between plankton communities and cetacean distributions have been found in the Georges Bank area of the Northwest Atlantic Ocean (Griffin, 1996). Analyses of Icelandic whale fishery statistics have demonstrated that whales concentrated their feeding along the axis of heaviest zooplankton densities (Foerster and Thompson, 1985). Acoustic detection of relative planktonic biomass in the Mediterranean Sea suggested sperm whales were most abundant in areas with higher plankton densities (Viale, 1991), and work has shown sperm whales were more abundant in areas of high production in the North Atlantic and South Pacific (Gulland, 1974; Jaquet and Whitehead, 1996).

Individual species or discrete biological communities may serve as tracers of water temperature or water mass history. Thermal gradients, structural heterogeneity of the continental shelf, and persistence of hydrographic fronts at continental shelf margins are important factors in zooplankton production (Sabates, et al., 1989), while water temperature and origin of water masses may affect copepod species distributions (Atkinson, et al., 1990). Zooplankton communities were temporally persistent in the near-shore planktonic ecosystem of southern California (Barnett and Jahn, 1987), in the Gulf Stream (Ashjian and Wishner, 1993), and in the North Sea (Williams, et al., 1993). Zooplankton biomass in the North Atlantic has been shown to be lowest in the Gulf Stream and Sargasso Sea, and increasing from the slope water/ Gulf Stream interface to a maximum above the shelf (Allison and Wishner, 1986; Ashjian, et al., 1994; Sherman, et al., 1988).
In this study it is hypothesized that zooplankton community structure can be used as an "indicator" variable in the habitat description of odontocete species. Although odontocetes are not known to utilize zooplankton as a food source, trophic relationships between their prey and the zooplankton community might indirectly influence odontocete foraging movements. Further, zooplankton taxa which are not part of a trophic web leading to Cetacea may still be useful as proxy measures for complicated interactions of hydrography and biology. This paper examines relationships of zooplankton abundance and diversity with odontocete distributions off the northeast coast of the United States and tests the hypothesis that zooplankton abundance and diversity are useful in understanding odontocete habitat utilization.

\section{Methods}

From 1 June to 2 July 1993 a United States National Oceanic and Atmospheric Administration, National Marine Fisheries Service (NOAA/NMFS) shipboard cetacean census was conducted along the eastern and southern edges of Georges Bank aboard the NOAA vessel Delaware II (Fig. 1a, b). During transects of the study area from the Scotian Shelf $\left(42.3^{\circ} \mathrm{N}, 65.0^{\circ} \mathrm{W}\right)$ to Veatch Canyon $\left(40.0^{\circ} \mathrm{N}\right.$, $\left.68.5^{\circ} \mathrm{W}\right)$, concurrent physical and biological data were collected to examine characteristics of marine mammal habitat. Cetaceans were sighted using $25 \times 150$ power binoculars. Survey protocol involved continuous effort from 0600-1900 hrs (EDST), with two observers scanning through binoculars, and a third observer (serving as data recorder) scanning unaided. Effort continued as sea state and weather conditions permitted.

Transects were designed to frequently traverse the shelf-break in a zig-zag pattern. At the end of each traverse, casts were made to determine hydrographic structure using a conductivity, temperature, depth bathythermograph (CTD), to a depth of $200 \mathrm{~m}$, or to within $10 \mathrm{~m}$ of bottom where bottom depth was less than $200 \mathrm{~m}$. Hydrographic data were received and archived on computer instantaneously.

Periodically, zooplankton were sampled simultaneously with the CTD recordings using the double oblique Bongo tow method. These stations were randomly selected at the end of transect lines. In this technique, a double "bongo" frame carrying two 


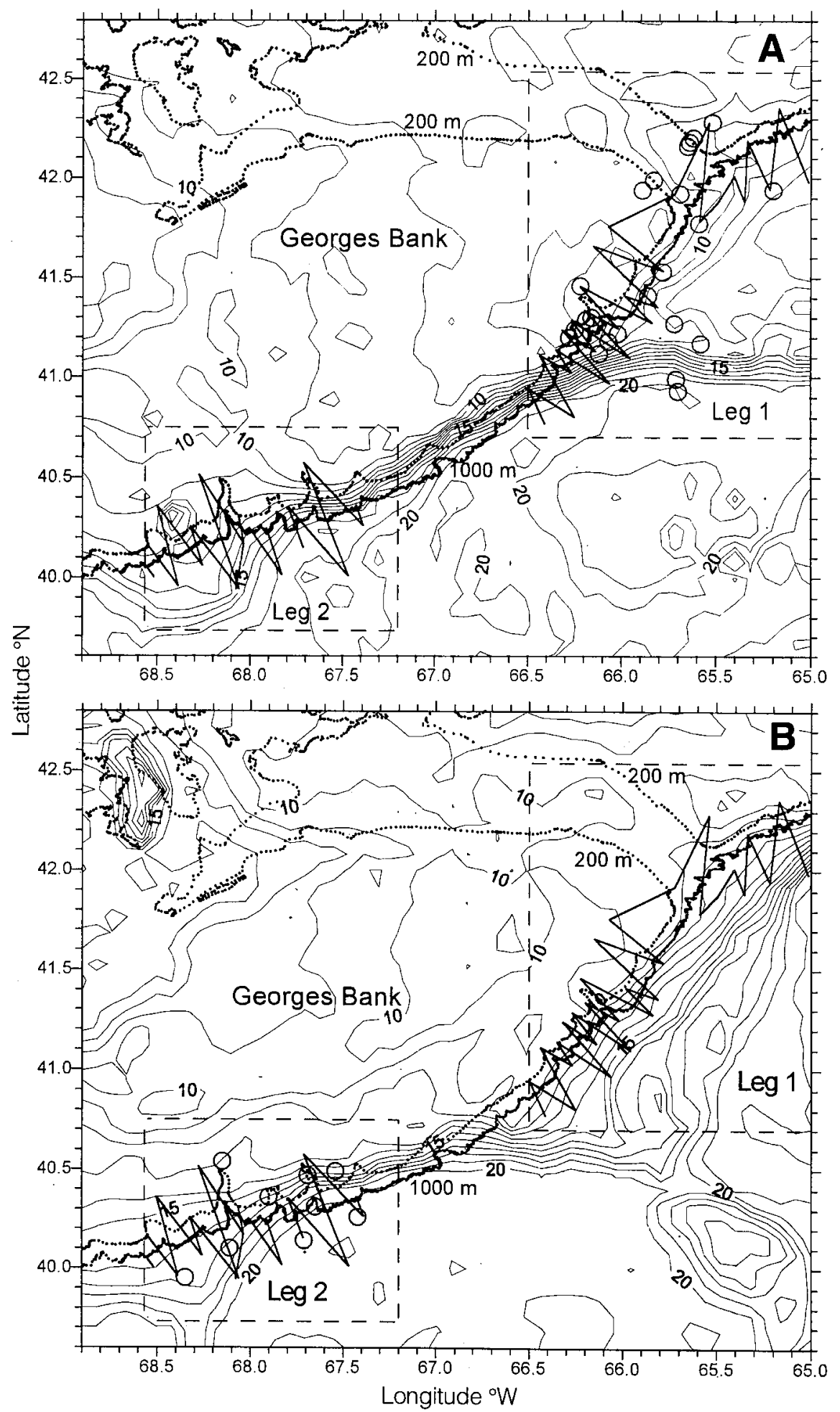

Fig. 1. Sea surface temperature ${ }^{\circ} \mathrm{C}$ (SST) during the survey. Zooplankton sampling sites are designated by circles. Depth contours of $200 \mathrm{~m}$ and $1000 \mathrm{~m}$ are shown. Survey trackline is shown within the region considered for these analyses. (A) Composite of SST, 2-8 June 1993. (B) Composite of SST, 23-28 June 1993. 
nets, one $303 \mu \mathrm{m}$ and one $505 \mu \mathrm{m}$ mesh, towed at a speed sufficient to maintain a $30^{\circ}$ incline from the verticle of the tow wire, was lowered to $200 \mathrm{~m}$ depth and retrieved. Surface temperatures were additionally recorded at 32 of the 36 stations sampled, which covered a variety of habitats (e.g. on-shelf/off-shelf, over canyon/inter-canyon).

In the laboratory, zooplankton samples were split, resulting in sub-samples of approximately 500 organisms. Zooplankton in sub-samples were analyzed for taxa and abundance, and copepods were identified to species level. Zooplankton density $\left(\right.$ per $\mathrm{m}^{3}$ ) was computed using abundance data and metered tow volume, and copepod and total organism abundances were log transformed (COPEPLOG) to compensate for potential curvilinearity. For copepods, a Shannon Diversity Index (SHANNON) was calculated from:

$$
H^{\prime}=-\Sigma p_{i} \ln \left(p_{i}\right)
$$

where $p_{i}$ is the decimal fraction of individuals belonging to the $i^{\text {th }}$ species and $H^{\prime}$ is the diversity index.

From the index, a measure of species abundance equitability $(J)$ was computed as:

$$
J=H^{\prime} / H_{\max }^{\prime}
$$

where $H_{\text {max }}^{\prime}$ is the value of $H^{\prime}$ computed with the same number of species, but equal $p_{i}$ values (Cox, 1985).

The CTD hydrographic data were summarized as 4 variables to quantify thermal structure: 1) maximum temperature above $200 \mathrm{~m}$ depth (TEMPMAX), 2) minimum temperature above $200 \mathrm{~m}$ depth (TEMPMIN), 3) the difference $\left({ }^{\circ} \mathrm{C}\right)$ between maximum and minimum temperatures (TEMPRANG), 4) water masses classified according to thermal structure (THERCLAS) as; a) thoroughly mixed over the entire water column sampled $=0, b)$ thermally stratified, with warm water overlying cooler water $=+1$, and c) thermally stratified, with a warm water mass underlying cooler water $=-1$. Additional hydrographic data were obtained by shipboard sampling (TEMPSURF), and from satellite images of sea surface temperature. Satellite images were processed such that temperature data were extracted from the images, and contours showing isotherms were computed using a kriging technique.
In addition to plankton and hydrographic variables, fixed geographic variables of bottom depth (m) (BOTM) and latitude (LAT) at station site, were examined for relationships with plankton and odontocete sightings. Longitude was not used as a variable in these analyses.

All recorded odontocete sightings were used, whether recorded during active search effort or sighted while diverting from track to further investigate prior sightings. Sightings were summarized as quantities representing total number of animals within $20 \mathrm{~km}$ of bongo stations. These quantities were corrected for effort by dividing total animals seen within $20 \mathrm{~km}$ of stations by total number of hours of effort within the block. Block data were used when total effort within a block was 2 hrs or greater. The block size of $20 \mathrm{~km}$ was selected as smaller scales were often characterized by less than $1 \mathrm{hr}$ of survey effort.

Standardized species sighting rates were calculated when any odontocete species was found in at least $50 \%$ of the survey blocks. These species included the common dolphin (Delphinus delphis), striped dolphin (Stenella coeruleoalba), Atlantic white-sided dolphin (Lagenorhynchus acutus), pilot whales (Globicephala spp.), sperm whales (Physeter macrocephalus) and beaked whales (Mesoplodon spp.). Mean group sizes of species by station were calculated as a function of total animals of a given species sighted, and total number of sightings of that species.

Specific odontocete species were analyzed for abundance and group size relationships with hydrographic conditions and zooplankton variables, when they were sighted within $20 \mathrm{~km}$ of 16 or more bongo stations (i.e. half of bongo stations with $>2 \mathrm{hrs}$ sighting effort within $20 \mathrm{~km}$ of stations). Due to the difficulty of identifying Globicephala and Mesoplodon species at sea, they were analyzed on a generic basis. Others were analyzed by species. Pearson's product-moment correlation coefficient method was used (Sokal and Rohlf, 1981), for correlations with environmental parameters.

\section{Results}

The research cruise consisted of 2 components: Leg 1, when sighting effort was deployed through 3 June to 11 June 1993 and Leg 2 during 16 June to 30 June 1993. During Leg 1, a warm core ring was 
positioned along the southeastern edge of Georges Bank. Sighting effort and bongo tows were conducted in cooler waters north of the ring (Fig. 1a). During Leg 2, the warm core ring had moved south, and a second warm core ring occupied the region of cooler water observed during Leg 1. Sighting effort and bongo tows were made in the interface between the southern warm core ring and cooler shelf water (Fig. 1b).

Copepod abundance ranged from 11-1 172 per $\mathrm{m}^{3}$, while total zooplankton abundance ranged from 16-1 189 per $\mathrm{m}^{3}$. Copepod diversity (Shannon Index) ranged from 0.02 to 1.43 , while equitability of abundance of species $(J)$ ranged from 0.02 to 0.86 . Surface temperature at bongo sites varied between $6.8^{\circ}$ and $22.0^{\circ} \mathrm{C}$, while temperatures recorded by the CTD varied between $3.9^{\circ}$ and $22.0^{\circ} \mathrm{C}$. Depth at sites ranged from 54 to $3000 \mathrm{~m}$.

Log transformed zooplankton abundances and measures of zooplankton diversity were significantly correlated with both fixed (e.g. latitude, bathymetry) and transient (e.g. temperature) physical variables (Table 1). Copepod abundances were greater in northern regions of the survey, and abundance decreased in deeper waters. Warmer water temperatures were correlated with lower copepod abundances, and copepod numbers were elevated in areas where warm water was found beneath cool water. It is noted that hydrographic conditions of warm water underlying cool water suggest the presence of a sub-surface thermal front. Diversity in the copepod community was highest in southern, offshore regions with warmer water temperatures.

Sighting rates (animals per hr) for delphinids and non-delphinid odontocetes were correlated with biological or physical variables (Table 2). Nondelphinid odontocetes tended to be sighted more frequently in warmer waters, in the vicinity of subsurface thermal fronts. Delphinids were more likely to be found in southern areas with warmer water, and off the shelf. Unlike non-delphinid odontocetes, delphinid abundances were significantly negatively correlated with zooplankton abundance, and positively correlated with copepod diversity.

Approximately $35 \%$ of tested relationships between species and environment were significant (Table 3), and most significant tests described relationships of common and striped dolphins with the environment. Common dolphins and striped dolphins were found in deeper, relatively warm water in regions where copepod diversity was high and abundances were low. Abundances were

TABLE 1. Pearson's product-moment correlations of physical parameters with zooplankton parameters. (See text for description of abbreviated variables). $n=33$; except BOTM, LAT, TEMPSURF, where $n=34$.

\begin{tabular}{lcr}
\hline \hline Variable & Coefficient & \multicolumn{1}{c}{$P$} \\
\hline & $\log _{10}\left(\right.$ Copepods per $\left.m^{3}\right)$ & \\
BOTM & -0.5086 & 0.002 \\
TEMPSURF & -0.6757 & 0.0001 \\
TEMPMAX & -0.8000 & 0.0001 \\
TEMPMIN & -0.6644 & 0.0001 \\
TEMPRANG & -0.5687 & 0.0006 \\
LAT & 0.5220 & 0.002 \\
THERCLAS & -0.6373 & 0.0001 \\
------------- & \\
& 0.3692 & 0.03 \\
BOTM & 0.8724 & 0.0001 \\
TEMPSURF & 0.8856 & 0.0001 \\
TEMPMAX & 0.7545 & 0.0001 \\
TEMPMIN & 0.6096 & 0.0002 \\
TEMPRANG & -0.7996 & 0.0001 \\
LAT & 0.7584 & 0.0001 \\
THERCLAS &
\end{tabular}


TABLE 2. Correlations of physical and zooplankton parameters with effort number of animals sighted per hour within $20 \mathrm{~km}$ of bongo stations. (See text for description of abbreviated variables). $n=30$ for variables except for TEMPSURF, BOTM and LAT, where $n=31$.

\begin{tabular}{|c|c|c|}
\hline Variable & $r$ & $P$ \\
\hline \multicolumn{3}{|c|}{ Delphinids } \\
\hline BOTM & 0.5856 & 0.0004 \\
\hline LAT & -0.6039 & 0.0003 \\
\hline TEMPSURF & 0.4036 & 0.02 \\
\hline THERCLAS & 0.3159 & 0.08 \\
\hline TEMPMAX & 0.4958 & 0.005 \\
\hline TEMPMIN & 0.3186 & 0.08 \\
\hline TEMPRANG & 0.4774 & 0.005 \\
\hline COPEPLOG & -0.4647 & 0.009 \\
\hline LOGORGAN & -0.4498 & 0.01 \\
\hline SHANNON & 0.5346 & 0.002 \\
\hline $\mathrm{J}$ & 0.5489 & 0.002 \\
\hline \multicolumn{3}{|c|}{ Non-delphinid odontocetes } \\
\hline BOTM & 0.0718 & 0.70 \\
\hline LAT & 0.0087 & 0.96 \\
\hline TEMPSURF & -0.3496 & 0.05 \\
\hline THERCLAS & -0.4857 & 0.006 \\
\hline TEMPMAX & -0.2764 & 0.13 \\
\hline TEMPMIN & -0.5696 & 0.0008 \\
\hline TEMPRANG & 0.1534 & 0.41 \\
\hline COPEPLOG & 0.1684 & 0.37 \\
\hline LOGORGAN & 0.1355 & 0.48 \\
\hline SHANNON & -0.3259 & 0.08 \\
\hline $\mathrm{J}$ & -0.2523 & 0.18 \\
\hline
\end{tabular}

negatively correlated with latitude for both striped $(r=0.5272, P=0.003)$ and common dolphins $(r$ $=-0.5219, P=0.003)$. Sperm whale numbers were greatest in deeper water, but were not correlated with physical variables or copepod abundances. Beaked whale sightings were associated with relatively warm surface temperatures in the vicinity of sub-surface thermal fronts, but were not correlated with copepod abundance. White-sided dolphins were sighted in regions of relatively cool surface water with low maximum temperatures in the upper $200 \mathrm{~m}$ of the water column. Pilot whales did not exhibit significant correlations with any measured physical or biological variables.

Delphinid group sizes were significantly correlated with many variables (Table 4), and groups were larger in warmer waters with greater vertical temperature range. Group size also decreased with decreasing copepod densities and increasing copepod diversity. Non-delphinid odontocete groups were larger in warmer water, but were not related to copepod densities. Only common dolphin group sizes showed significant relationships with copepod density and diversity (Table 5). Mean group sizes were greater when copepod densities were low and diversity high.

\section{Discussion}

In these analyses, over 100 correlations have been examined. Theoretically, with an alpha of 0.05 , approximately 5 tests showing significant correlations will be in error. In these data 
TABLE 3. Correlations of zooplankton and physical parameters with effort as number of animals sighted per hour within $20 \mathrm{~km}$ of bongo stations, by species, where species were sighted within $20 \mathrm{~km}$ of at least 16 stations. (See text for description of abbreviated variables). $n=30$ for variables except for TEMPSURF and BOTM where $n=31$.

\begin{tabular}{|c|c|c|}
\hline Variable & $r$ & $P$ \\
\hline \multicolumn{3}{|c|}{ Common Dolphins } \\
\hline COPEPLOG & -0.5549 & 0.002 \\
\hline SHANNON & 0.5596 & 0.001 \\
\hline $\mathrm{J}$ & 0.5596 & 0.001 \\
\hline TEMPSURF & 0.4800 & 0.005 \\
\hline TEMPMAX & 0.5075 & 0.004 \\
\hline TEMPRANG & 0.3241 & 0.08 \\
\hline Вотм & 0.5474 & 0.001 \\
\hline THERCLAS & 0.4526 & 0.01 \\
\hline \multicolumn{3}{|c|}{ Striped Dolphins } \\
\hline COPEPLOG & -0.4214 & 0.02 \\
\hline SHANNON & 0.4714 & 0.009 \\
\hline $\mathrm{J}$ & 0.4964 & 0.005 \\
\hline TEMPSURF & 0.2583 & 0.15 \\
\hline TEMPMAX & 0.4136 & 0.02 \\
\hline TEMPRANG & 0.4286 & 0.02 \\
\hline ВОТМ & 0.5840 & 0.0004 \\
\hline THERCLAS & 0.2344 & 0.20 \\
\hline \multicolumn{3}{|c|}{ Sperm Whales } \\
\hline COPEPLOG & 0.1031 & 0.59 \\
\hline SHANNON & -0.1519 & 0.42 \\
\hline $\mathrm{J}$ & -0.1307 & 0.49 \\
\hline TEMPSURF & -0.1069 & 0.56 \\
\hline TEMPMAX & 0.0760 & 0.68 \\
\hline TEMPRANG & 0.2975 & 0.10 \\
\hline ВОтм & 0.5346 & 0.002 \\
\hline THERCLAS & -0.2160 & 0.24 \\
\hline
\end{tabular}

\begin{tabular}{lrc}
\hline \hline Variable & $r$ & $P$ \\
\hline & Beaked Whales & \\
COPEPLOG & 0.1669 & 0.38 \\
SHANNON & -0.2725 & 0.15 \\
J & -0.1731 & 0.36 \\
TEMPSURF & -0.4317 & 0.01 \\
TEMPMAX & -0.3004 & 0.10 \\
TEMPRANG & 0.0452 & 0.81 \\
BOTM & 0.0071 & 0.97 \\
THERCLAS & -0.4534 & 0.01
\end{tabular}

\begin{tabular}{lcr} 
& White-sided Dolphins & \\
COPEPLOG & 0.2028 & 0.28 \\
SHANNON & -0.3078 & 0.10 \\
J & -0.2243 & 0.23 \\
TEMPSURF & -0.5545 & 0.001 \\
TEMPMAX & -0.3512 & 0.05 \\
TEMPRANG & -0.0571 & 0.76 \\
BOTM & 0.1192 & 0.52 \\
THERCLAS & -0.0960 & 0.61 \\
--------1 & \\
& Pilot & 0.09 \\
COPEPLOG & 0.3195 & 0.19 \\
SHANNON & -0.2475 & 0.10 \\
J & -0.3053 & 0.73 \\
TEMPSURF & 0.0632 & 0.53 \\
TEMPMAX & -0.1181 & 0.73 \\
TEMPRANG & -0.0645 & 0.06 \\
BOTM & -0.3337 & 0.11 \\
THERCLAS & -0.2963 & \\
\hline
\end{tabular}

52 correlations were significant at alpha $=0.05$. Care should be taken in interpreting results of multiple correlations.

The positive correlation of delphinid sighting rate with bottom depth (Table 2) suggests delphinids sighted during this survey were primarily inhabitants of shelf-break or deeper waters. The Cetacean and Turtle Assessment Program described whitesided dolphins as shelf inhabitants, while slope and pelagic cetaceans included the sperm whale, beaked whale, pilot whale, Risso's dolphin (Grampus griseus), bottlenose dolphin (Tursiops truncatus), common dolphin, and striped dolphin (CETAP, 1982). In this study, the sperm whale, common dolphin and striped dolphin sighting rates were positively correlated with bottom depth, while white- sided dolphin sighting rates were negatively correlated with depth.

Bathymetry indirectly affects cetacean distributions through its effect on current flow, upwelling of nutrients, and subsequent biological production. While bathymetry was an important selective pressure in the early evolutionary development of the Cetacea (Gaskin, 1976), it only varies on geological time scales. To understand variation in odontocete species distributions, we must examine interactions of biology and hydrography. While water temperature per se may not be important in determining habitat use, temperature boundaries are dynamic zones and are frequently sites of higher productivity. Cetaceans may actively search for these physical features. 
TABLE 4. Pearson's correlations of zooplankton and physical parameters with mean group size of animals sighted within $20 \mathrm{~km}$ of bongo stations. (See text for description of abbreviated variables). $n=30$ for COPEPLOG, SHANNON and $\mathrm{J} ; n=31$ for TEMPMAX and TEMPRANG; $n=32$ for TEMPSURF.

\begin{tabular}{lcr}
\hline \hline Variable & $r$ & \multicolumn{1}{c}{$P$} \\
\hline \multicolumn{3}{c}{ Delphinids } \\
COPEPLOG & -0.6310 & 0.0002 \\
SHANNON & 0.6372 & 0.0002 \\
J & 0.6165 & 0.0003 \\
TEMPSURF & 0.5503 & 0.001 \\
TEMPMAX & 0.6086 & 0.0003 \\
TEMPRANG & 0.4148 & 0.02 \\
------------ \\
& & \\
COPEPLOG & Non-delphinid odontocetes & 0.35 \\
SHANNON & 0.1782 & 0.27 \\
J & -0.2093 & 0.58 \\
TEMPSURF & -0.1055 & 0.05 \\
TEMPMAX & -0.3430 & 0.10 \\
TEMPRANG & -0.3305 & 0.85 \\
\hline
\end{tabular}

TABLE 5. Pearson's correlations of zooplankton parameters with mean group size of selected delphinid species sighted within $20 \mathrm{~km}$ of bongo stations (See text for description of abbreviated variables).

\begin{tabular}{|c|c|c|}
\hline Variable & $r$ & $P$ \\
\hline \multicolumn{3}{|c|}{ Common Dolphins $(n=20)$} \\
\hline COPEPLOG & -0.5766 & 0.008 \\
\hline SHANNON & 0.6456 & 0.002 \\
\hline $\mathrm{J}$ & 0.6430 & 0.002 \\
\hline \multicolumn{3}{|c|}{ Striped Dolphins $(n=16)$} \\
\hline COPEPLOG & 0.0371 & 0.89 \\
\hline SHANNON & 0.0223 & 0.93 \\
\hline $\mathrm{J}$ & 0.0408 & 0.88 \\
\hline \multicolumn{3}{|c|}{ Pilot Whales $(n=25)$} \\
\hline COPEPLOG & 0.1657 & 0.43 \\
\hline SHANNON & -0.2376 & 0.25 \\
\hline $\mathrm{J}$ & -0.2820 & 0.17 \\
\hline \multicolumn{3}{|c|}{ White-sided Dolphins $(n=17)$} \\
\hline COPEPLOG & 0.1141 & 0.66 \\
\hline SHANNON & 0.2366 & 0.36 \\
\hline $\mathrm{J}$ & 0.4466 & 0.07 \\
\hline
\end{tabular}

Delphinid sighting rates were significantly correlated with both physical and biological parameters (Tables 2, 3). The high degree of correlation between physical and biological data raises the question of which variables were acting as causal factors for delphinid distribution. Prior studies have concentrated on cetacean distributions as a function of water thermal structure and depth (CETAP, 1982; Fiedler and Reilly, 1994).

Copepod densities were greater in regions where thermal fronts were present. High copepod abundances and low diversity in cooler waters surveyed during Leg 1, and low copepod abundance and high diversity in warmer waters surveyed during Leg 2, likely resulted from presence of a warm core ring. Common dolphin and striped dolphin sighting rates were negatively correlated with copepod abundances, and positively correlated with copepod diversity. This finding suggests similar optimum habitat requirements between the two species. In the region of this study, a frontal boundary of approximately $15^{\circ} \mathrm{C}$ roughly separated cool shelf and slope water from the warmer water of a warmcore ring (Fig. 2). A Chi-Square analysis (Sokal and Rohlf, 1981) revealed striped dolphins were not preferentially distributed on either side of the isotherm $(P>0.10)$, but $80 \%$ of common dolphin sightings were on the cool side of the isotherm.

Although zooplankton data in this study suggested common and striped dolphins might live in similar trophic environments, hydrographic data suggested dissimilar habitats. Further research is needed to discover differences between these species in biotic resource utilization. Studies of distributional patterns of cetaceans should always gather abiotic and biotic data. Sampling zooplankton communities with the double oblique bongo tow method can be done quickly when censusing marine mammal populations and comparing zooplankton community structure with cetacean abundance may be helpful in determining biological parameters affecting cetacean distribution.

\section{Acknowledgements}

Nancy Griffin collected and archived oceanographic data, and assisted in sampling and processing zooplankton samples. T. Napora provided an education in identification of copepods. 


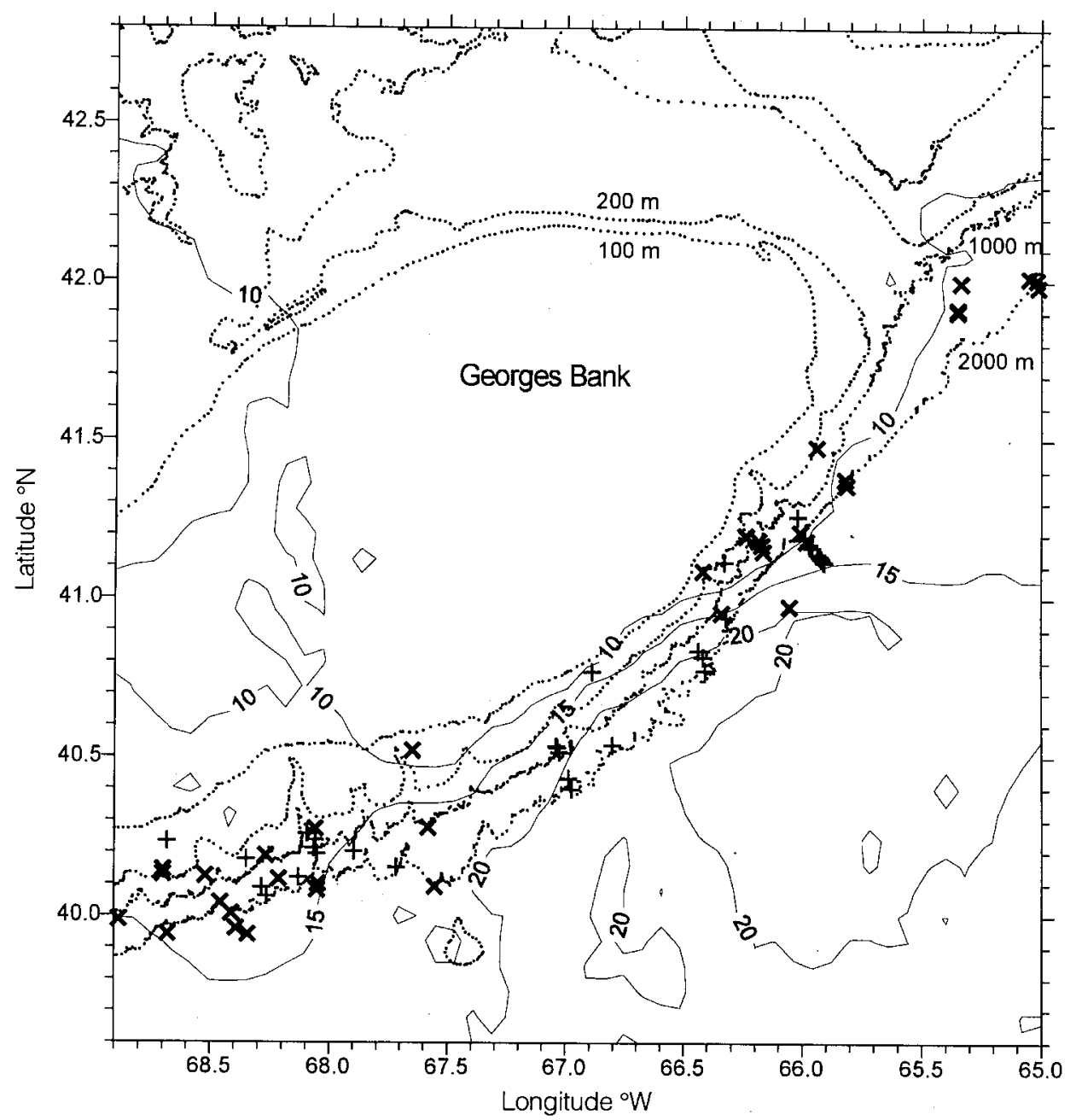

Fig. 2. Spatial location of common dolphin and striped dolphin sightings along the eastern edge of Georges Bank during June 1993 , with $10^{\circ} \mathrm{C}, 15^{\circ} \mathrm{C}$ and $20^{\circ} \mathrm{C}$ sea surface temperature contours shown. Common dolphins $=\times$, Striped dolphins $=+$. Depth contours of $100 \mathrm{~m}, 200 \mathrm{~m}, 1000 \mathrm{~m}$, and $2000 \mathrm{~m}$ are shown.

Tim Smith provided encouragement in initiating this study, and Gordon Waring, chief scientist, provided time for data collection. Candace Oviatt and two anonymous reviewers provided helpful criticism of an earlier version of this paper. Work reported herein was done in partial fulfillment of the requirements for the degree of Ph.D. Partial funding was provided by the URI/NOAA CMER Program.

\section{References}

ALLISON, S. K. and K. F. WISHNER. 1986. Spatial and temporal patterns of zooplankton biomass across the Gulf Stream. Mar. Ecol. Prog. Ser., 31: 233-244.
ASHJIAN, C. J. and K. F. WISHNER. 1993. Temporal persistence of copepod species groups in the Gulf Stream. Deep-Sea Res. 1, 40: 483-516.

AShJiAn, C. J., S. L. SMith, C. N. FlaGG, A. J. MARIANO, W. J. BEHRENS, and P. V. Z. LANE. 1994. The influence of a Gulf Stream meander on the distribution of zooplankton biomass in the Slope Water, the Gulf Stream, and the Sargasso Sea, described using a shipboard acoustic Doppler current profiler. Deep-Sea Res. 1, 41: 23-50.

ATKINSON, A., P. WARD, J. M. PECK, and A. W. A. MURRAY. 1990. Mesoscale distribution of zooplankton around South Georgia. Deep-Sea Res. 1., 37: 1213-1227.

BARNETT, A. M. and A. E. JAHN. 1987. Pattern and persistence of a nearshore planktonic ecosystem off 
Southern California. Cont. Shelf Res., 7: 1-25. CETACEAN AND TURTLE ASSESSMENT PROGRAM (CETAP). 1982. A Characterization of Marine Mammals and Turtles in the Mid- and North Atlantic Areas of the U. S. Outer Continental Shelf, Final Report. Contract No. AA551-CT8-48, U. S. Department of the Interior, Bureau of Land Management, Washington, D.C., 584 p.

COX, G.W. 1985. Laboratory Manual of General Ecology, Fifth Edition. Wm. C. Brown Publishers. Dubuque, Iowa.

DOYLE, M.J., and T.A. RYAN. 1989. Spatial patterns in a coastal ichthyoplankton community southwest of Ireland. The Early Life History of Fish. The Third ICES Symposium, Bergen, 3-5 October 1988, 191: 70-84.

FIEDLER, P. C., and S. B. REILLY. 1994. Interannual variability of dolphin habitats in the eastern tropical Pacific. II.: Effects on abundances estimated from tuna vessel sightings, 1975-1990. Fish. Bull., 92: 451-463.

FOERSTER, J. W. and P. M. THOMPSON. 1985. Plankton and whaling ground dynamics in the Denmark Strait. International Symposium on Marine Plankton, Bull. Mar. Sci., 37: 504-517.

GASKIN, D. E. 1976. The evolution, zoogeography and ecology of cetacea. Oceanogr. Mar. Biol. Ann. Rev., 14: 247-346.

GRIFFIN, R. B. 1996. Community ecology of cetacean habitat. Doctoral Dissertation. University of Rhode Island, Graduate School of Oceanography, Narragansett, R.I., 200 p.

GULLAND, J. A. 1974. Distribution and abundance of whales in relation to basic productivity. In: The Whale Problem. W. E. Schevill, (ed.). Harvard University Press, Cambridge, MA, p. 27-52.

INTERNATIONAL WHALING COMMISSION. 1992. Report of the Scientific Committee. Rept. Int. Whal. Comm., 42: 52, 60.

JAQUET, N. and H. WHITEHEAD. 1996. Scale-dependent correlation of sperm whales distribution with environmental features and productivity in the South Pacific. Mar. Ecol. Prog. Ser., 135: 1-9.

PEPIN, P. 1990. Biological correlates of recruitment variability in North Sea fish stocks. ICES J. Cons., 47: 89-98.

POLACHECK, T. 1987. Relative abundance, distribution and inter-specific relationship of cetacean schools in the eastern tropical Pacific. Mar. Mam. Sci., 3: 54-77.

REILLY, S. B., and P. C. FIEDLER. 1994. Interannual variability of dolphin habitats in the eastern tropical Pacific. I: Research vessel survey, 1986-1990. Fish. Bull., 92: 434-450.

SABATES, A., J. M. GILI, and P. PAGES. 1989. Relationship between zooplankton distribution, geographic characteristics and hydrographic patterns off the Catalan coast (western Mediterranean). Mar. Biol., 103: 153-159.

SELZER, L. A., and P. M. PAYNE. 1988. The distribution of white-sided (Lagenorhynchus acutus) and common dolphins (Delphinus delphis) vs environmental features of the continental shelf of the northeastern United States. Mar. Mamm. Sci., 4: $141-153$.

SHERMAN, K., M. GROSSLEIN, D. MOUNTAIN, D. BUSCH, J. O'REILLY, and R. THEROUX. 1988. The continental shelf ecosystem of the northeast coast of the United States. In: Ecosystems of the World 27: Continental Shelves. H. Postma and J.J. Zijlstra, (eds.). Elsevier. New York, p. 279-387.

SMITH, T. D., R. B. GRIFFIN, G. WARING, and J. G. CASEY. 1996. Multispecies Approaches to Management of Large Marine Predators. In: The Northeast Shelf Ecosystem: Assessment, Sustainability, and Management. K. Sherman, N. A. Jaworski, and T. J. Smayda, (eds.). Blackwell Science, Cambridge, MA, p. 467-490.

SOKAL, R. R., and F. J. ROHLF. 1981. Biometry, Second Edition. W. H. Freeman and Company. 859 p.

STONE, H. H., and JESSOP, B. M. 1992. Seasonal distribution of river herring Alosa pseudoharengus and A. aestivalis off the Atlantic coast of Nova Scotia. Fish. Bull., 90: 376-389.

VIALE, D. 1991. A synoptic method of localising productive marine areas by simultaneous detection of cetacean, thermic fronts and submarine biomasses. Ann. Inst. Oceanogr., 67: 4962.

WARING, G. T. 1995. Fishery and ecological interactions for selected cetaceans, off the northeast U.S.A. Doctoral Dissertation. University of Massachusetts, Amherst, MA. 260 p.

WILliAMS, R., J. A. LINDLEY, H. G. HUNT, and N. R. COLLINS. 1993. Plankton community structure and geographical distribution in the North Sea. J. Mar. Biol. Ecol., 172: 143-156. 